\title{
Keratoconus: Tissue Engineering and Biomaterials
}

\section{Dimitrios Karamichos $^{1, *}$ and Jesper Hjortdal ${ }^{2}$}

1 Department of Ophthalmology, University of Oklahoma Health Sciences Center, 608 Stanton L. Young Blvd, DMEI PA-409, Oklahoma City, OK 73104, USA

2 Department of Ophthalmology, Aarhus University Hospital, Aarhus C DK-800, Denmark; E-Mail: jesper.hjortdal@dadlnet.dk

* Author to whom correspondence should be addressed; E-Mail: dimitrios-karamichos@ouhsc.edu.

Received: 11 August 2014; in revised form: 26 August 2014 / Accepted: 3 September 2014 /

Published: 11 September 2014

\begin{abstract}
Keratoconus (KC) is a bilateral, asymmetric, corneal disorder that is characterized by progressive thinning, steepening, and potential scarring. The prevalence of $\mathrm{KC}$ is stated to be 1 in 2000 persons worldwide; however, numbers vary depending on size of the study and regions. KC appears more often in South Asian, Eastern Mediterranean, and North African populations. The cause remains unknown, although a variety of factors have been considered. Genetics, cellular, and mechanical changes have all been reported; however, most of these studies have proven inconclusive. Clearly, the major problem here, like with any other ocular disease, is quality of life and the threat of vision loss. While most $\mathrm{KC}$ cases progress until the third or fourth decade, it varies between individuals. Patients may experience periods of several months with significant changes followed by months or years of no change, followed by another period of rapid changes. Despite the major advancements, it is still uncertain how to treat $\mathrm{KC}$ at early stages and prevent vision impairment. There are currently limited tissue engineering techniques and/or "smart" biomaterials that can help arrest the progression of $\mathrm{KC}$. This review will focus on current treatments and how biomaterials may hold promise for the future.
\end{abstract}

Keywords: keratoconus; in vitro; corneal cells; tissue engineering; biomaterials 


\section{Introduction}

Keratoconus $(\mathrm{KC})$ is a bilateral degenerative non-inflammatory corneal disorder with prevalence of 1 in 2000 people worldwide, although this number varies considerably between studies [1-10]. While $\mathrm{KC}$ is observed in populations throughout the world, it is reported more frequently in certain ethnic groups such as South Asians, Eastern Mediterranean, and North Africans [11-13]. The incidence is believed to be as high as 1 in 500 [2] but difficulties with differential diagnosis causes uncertainty as to its prevalence. $\mathrm{KC}$ is known to typically initiate at puberty and progress until the third or fourth decade when it usually arrests [14-16]. The rate of the progression varies significantly between individuals and not everyone will experience severe stages of the disease. It is estimated that $10 \%-15 \%$ of $\mathrm{KC}$ diagnosed patients will reach severe stages and require corneal transplantation in order to have functional vision [1-16].

At early stages, patients typically experience minor blurring with the symptoms being identical to refractive defect and irregular astigmatism [3,17-19]. As KC progresses, vision deteriorates. The degree of vision impairment depends on the rate of progression. At mid-stages, $\mathrm{KC}$ is easily diagnosed and patients experience trouble with their night vision, photophobia, eye strain, and eye itching [20-23]. Most of the time, advanced KC stages develop corneal scarring which contributes to further vision loss and ultimately makes corneal transplantation necessary.

This disease has a profound effect on patients and may result in significant difficulties with conducting every day activities. Previous reviews have concentrated on management of the disease and clinical/surgical options [3,24-30] and will be discussed briefly here. The reality is that most of the treatments are available to improve the quality of life but not necessarily to treat the disease. Even with the recent success of collagen cross-linking with riboflavin (or CXL), there are still questions with regard to its long-term efficiency. CXL was first introduced in Europe about 10 years ago and is currently in clinical trials in USA [31-35]. Time will only tell whether this technology arrests the disease for life or just delays the process.

The purpose of this review is to outline current techniques to arrest $\mathrm{KC}$ disease and discuss promising tissue engineering techniques and biomaterials that are available but have never been tested on $\mathrm{KC}$.

\section{Pathophysiology and Etiology}

It is widely believed that genetics, the environment, and the cellular mechanism all play a role in $\mathrm{KC}[9,36-49]$. However, the exact contribution of each of the above to the etiology of $\mathrm{KC}$ is unknown. It is almost certain that $\mathrm{KC}$ is a multifactorial disease and the onset is still a mystery. $\mathrm{KC}$ has its onset at puberty and it can progress until the third or fourth decade of life; however, it can arrest at any point $[3,50]$. While multiple reports have associated $\mathrm{KC}$ with other disorders, it is more commonly seen as an isolated condition. The most common disorders associated with $\mathrm{KC}$ are Down syndrome and Leber's congenital amaurosis [40,51-54]. Rabinowitz's 1998 review discussed these studies [3]. In some cases, $\mathrm{KC}$ appears to have a familial association. However, in a study at the Cedars-Sinai Medicine Center, authors found that $99 \%$ of the $300 \mathrm{KC}$ patients had no association with genetic diseases $[3,54,55]$.

In terms of sex preference of the disease, it seems to affect both male and female [56]. In fact, female or male dominance is unclear based on data reported from various studies. Some studies report a 
preponderance of men over women and others report the exact opposite [5,7,56-63]. It is known, however, that higher numbers of KC disorders are seen in the South Asian region.

One of the most common associations of $\mathrm{KC}$ is eye rubbing [59,64-68]. This environmental cause was first introduced by Ridley who discovered the relationship between KC and atopic disease [69]. In Ridley's study, more that $70 \%$ of KC patients vigorously rubbed their eyes [69]. Further support of this theory was provided by subsequent studies [70]. Other environmental factors include poorly fit contact lenses and allergies [70-73]. The relationship between $\mathrm{KC}$ and contact lenses or allergies is still questioned by scientists and further studies are needed. In both cases, however, eye rubbing is a possible confounder.

Cellular dysfunction and biochemical abnormalities are almost certain to play a role in $\mathrm{KC}$ onset as well as progression. Various authors have suggested abnormalities in collagen fibers within the cornea and their cross-linking. Others have reported abnormalities in proteoglycans and proteoglycan metabolism of the cornea [41-49]. One recent discovery is the abnormal processing of superoxide radicals in $\mathrm{KC}$ corneas and the involvement of oxidative stress in KC [74-77]. This is now linked to the quality of tears and the disruption on collagen structure due to the creation of harmful byproducts of cell metabolism.

Overall, there are many potential candidates for the onset and progression of the $\mathrm{KC}$ disease. These candidates (genetic, environmental, cellular, or other factors) may be acting alone or in combination, leading to a vision threatening condition.

\section{Clinical Characteristics and Management}

The disease may progress very fast or very slow or may even stop at early stages without any further complications. In any scenario, patients that reach severe stages require some kind of clinical intervention. Below, we briefly discuss the three main options available to patients. Other options are available and have been reviewed elsewhere [1,40,78-103].

\subsection{Penetrating Keratoplasty (PKP)}

It is estimated that approximately $10 \%-15 \%$ of $\mathrm{KC}$ cases will progress to an extent which requires surgical intervention $[1,100,101,104]$. Once the cornea becomes excessively ectatic, thin or scarred, no correction can help the patient. Contact lenses cannot be worn or will not improve visual acuity and therefore corneal transplantation is required. Overall, penetrating keratoplasty (or PKP) is the most common procedure (Figure 1) for individuals with severe KC [105]. Generally, PKP is a successful procedure for KC patients, with favorable results [1,106-109]. Niziol (2013) [108] recently reported a $90 \%$ success rate for 5-12 year-old grafts. There have been multiple studies with various populations and number of patients, such as from Lim and co-authors [110], reporting a success rate of $95.7 \%$ from a total of 93 eyes receiving PKP [110,111]. From the recent literature, it seems that graft survival is improving. In 1972, Keates et al. [111] reported a success rate slightly over 80\%. A little later, Troutman and co-authors reported an $88.4 \%$ success rate [112]. The acute recovery of someone receiving PKP is anywhere between 4 and 6 weeks, but stable vision is not achievable for at least a year post-op $[101,105]$. Any complications following PKP are related to vascularization and rejection of the donor cornea. Other known but rare complications, are cataract, loose suture, glaucoma, and severe astigmatism [113-117]. 
Overall, this is a safe surgical option which is heavily used by surgeons. The huge drawback is the availability of donor corneas, especially in under-developed countries.

Figure 1. Penetrating keratoplasty. (A) Distorted cornea removed; (B) Corneal graft placed in recipient bed; $(\mathbf{C})$ "Stay sutures" placed; (D) Single running suture in place at end of surgery.
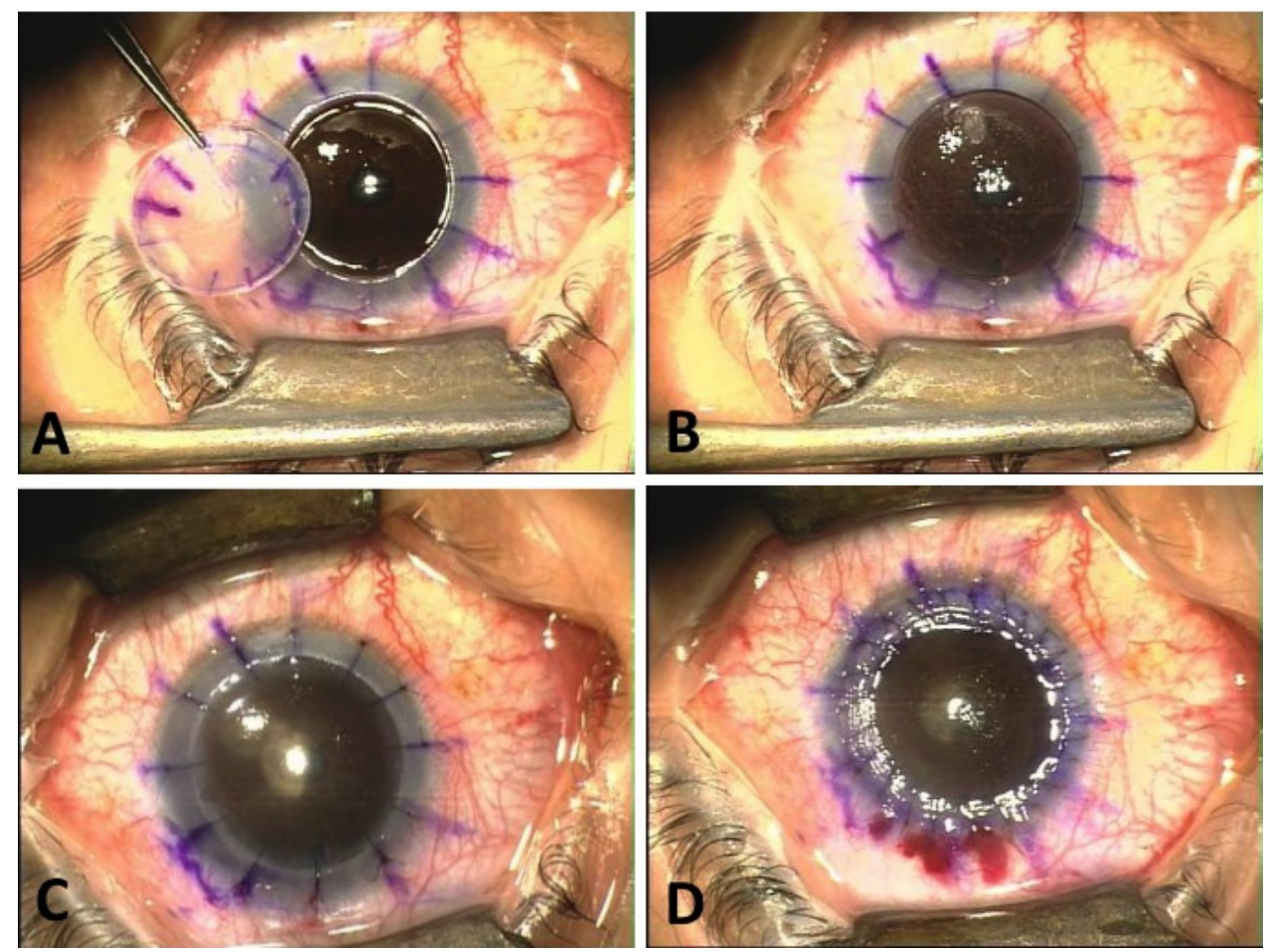

\subsection{Deep Anterior Lamellar Keratoplasty (DALK)}

Deep anterior lamellar keratoplasty (DALK) is a relatively new technique and so far it has been very promising [118]. In DALK (Figure 2), surgeons remove the corneal epithelium and stroma, but not the endothelium, from the host cornea. This is a major advantage over PKP since preservation of host endothelium reduces the risk of graft rejection. The actual surgery is challenging and requires expertise. In fact, a variety of DALK modifications have been reported and recently reported by Fogla [119], including "peeling technique" [120], intrastromal air injection [121], and hydro-delamination [122]. Our data on DALK is rather premature since it was only introduced to keratoconus patients in the mid-90s [123-126]. However, the post-op results so far have been promising. An average of $80 \%$ of KC patients showed 20/40 visual acuity after receiving DALK [127-129]. For many surgeons, DALK is the "next big thing" and an alternative to PKP. DALK significantly minimizes common PKP complications such as wound leakage and endothelial graft rejection, but Descement membrane perforation [122,129-132], secondary anterior chamber formation [133], and interface keratitis [134] can develop as a result of DALK. 
Figure 2. Deep anterior keratoplasty (DALK). (A) After partial trephination, a cannula is inserted deep in the corneal stroma; (B) Air injection through the cannula separating Descemets membrane from stroma; (C) Manual dissection ensuring that only the recipient's Descemets membrane is preserved; (D) Lamellar donor graft sutured in place at end of surgery.
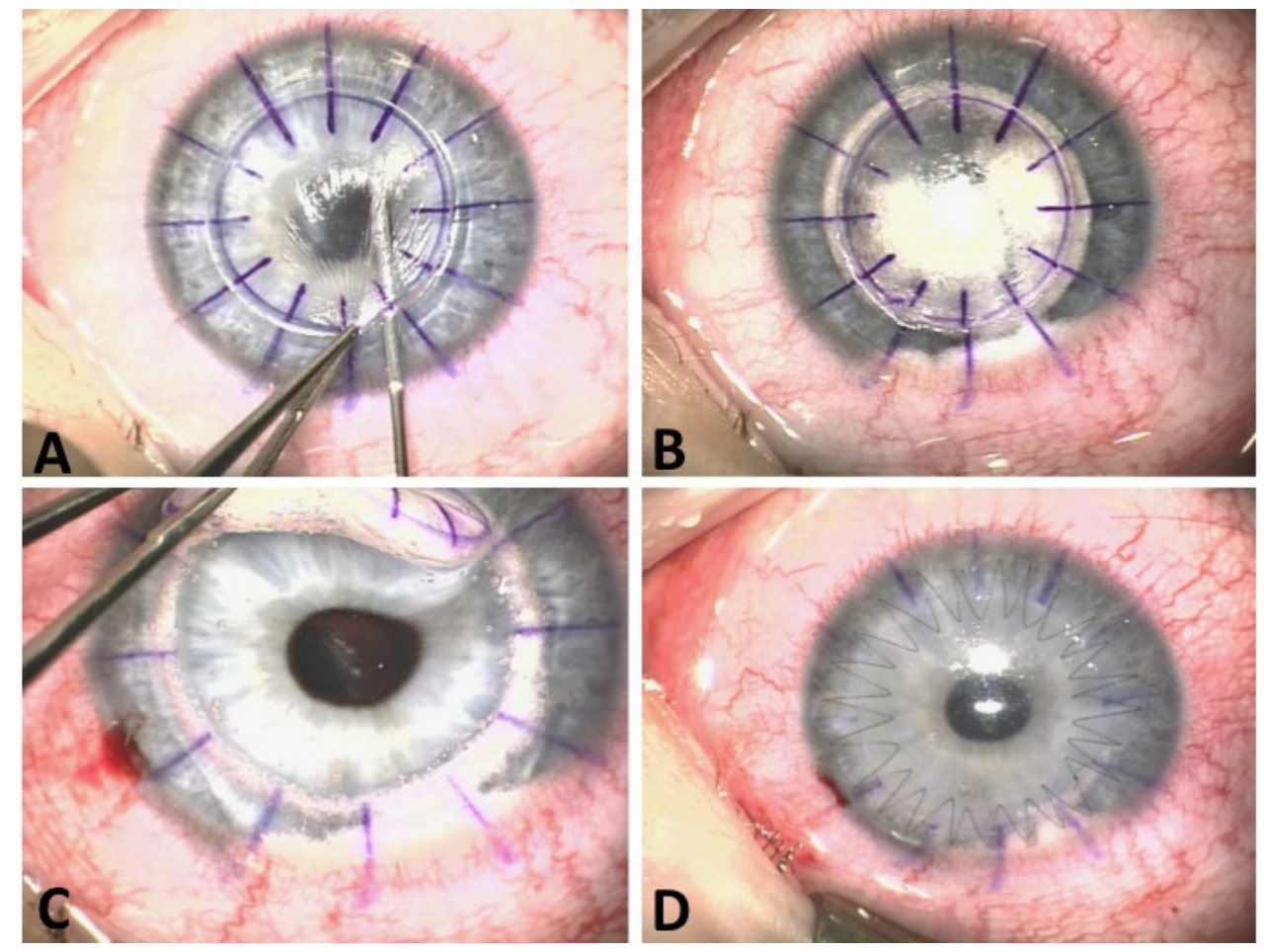

\subsection{Intrastromal Ring Segments (INTACS)}

Intrastromal ring segments (INTACS) are polymethyl methacrylate and acrylic polymer inserts that were originally designed for myopia correction purposes [135-140]. Currently, they are used as an effective treatment for mild to moderate keratoconus [135,141-159]. The major function of INTACS is to reshape $\mathrm{KC}$ corneas to a more regular cornea surface and allow better contact lens fitting and therefore improve vision $[141,160]$. During an INTACS operation, no cornea tissue is removed and overall, the surgery is less invasive. INTACS are placed within the cornea (one on each side) to lift the inferior or superior ectasia and flatten the bulged cornea area of KC [141,160]. Colin and co-authors [161] were the first to apply INTACS to KC patients. Since then, there have been a number of studies reporting results on INTACS [135,143,144,146-159,162]. Overall, INTACS are a good option in order to temporarily improve contact lens fitting and vision (Figure 3). INTACS are not used as a treatment to arrest KC disease, but they hold a lot of promise in delaying the need for PKP and other invasive surgical solutions. 
Figure 3. Intracorneal ring segments. Scheimpflug image inserts show keratoconic cornea before and after insert of one intracorneal ring segment. Color images show corneal power before and after a segment insert and the change in corneal power. Note that corneal power after segment implantation is more regular.

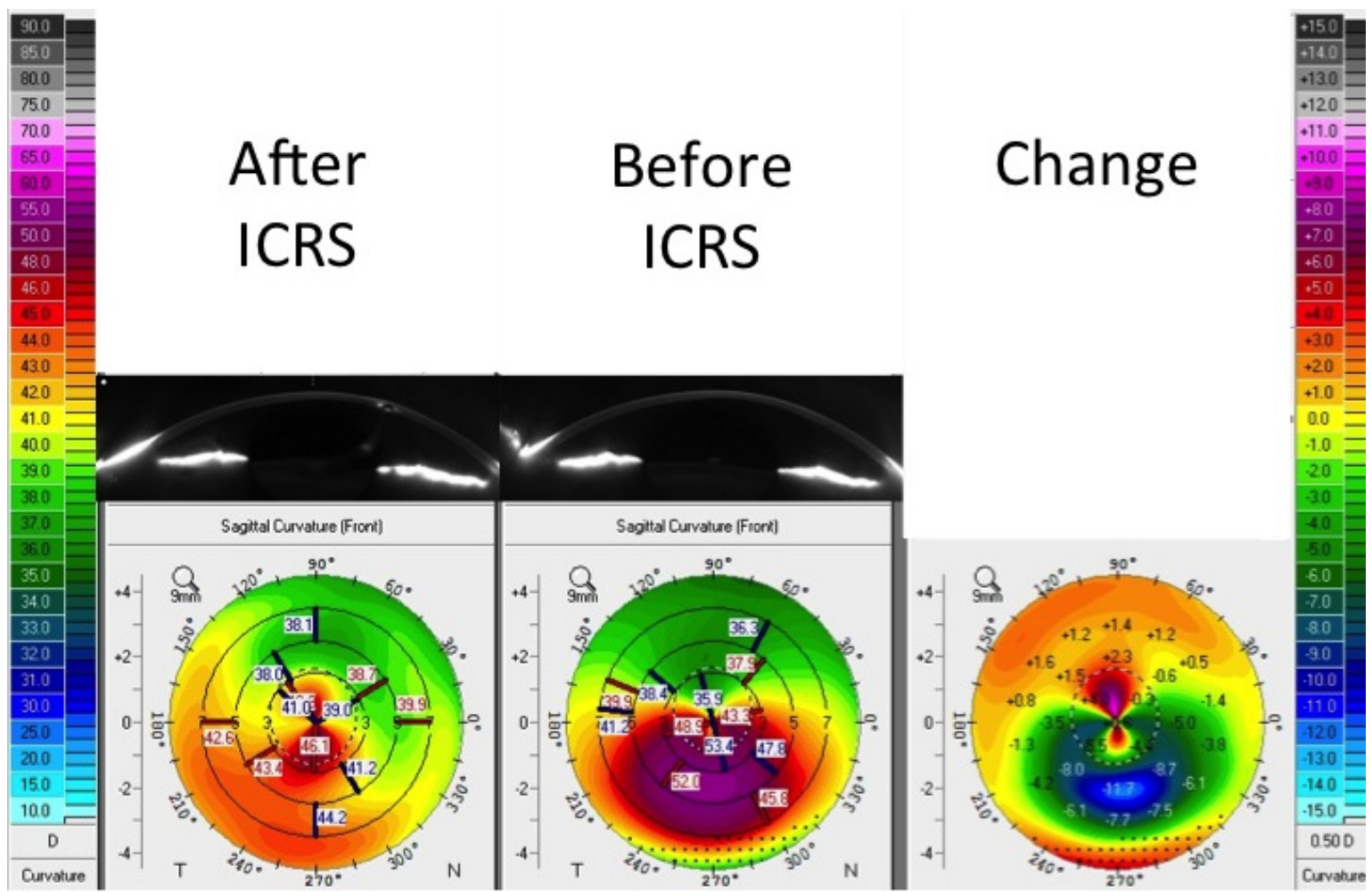

\subsection{Corneal Crosslinking (CXL)}

The potential of ultraviolet-A light (UVA) to crosslink tissues in the presence of riboflavin has been known for some time. However, it was not until 1998 that this strategy was proposed as a therapeutic corneal treatment. Since then, interventions have been performed in Europe, while in the USA clinical trials were initiated in 2008 and are awaiting FDA approval. The procedure is relatively easy and well documented. Briefly, CXL is achieved via application of riboflavin solution (Figure 4) over $30 \mathrm{~min}$ on the de-epithelialization cornea, followed by UV-A illumination for approximately $30 \mathrm{~min}$ or less [163-167]. Activated riboflavin results in the formation of new bonds across adjacent corneal stroma collagen strands and ground substance, ultimately leading to strengthening of corneal stroma mechanics. In case of $\mathrm{KC}$, this is currently used routinely in Europe and the treatment in most cases arrests the disease progression [168-174]. The routinely used technique is performed with the epithelium layer removed from the corneal stroma in order to ensure better riboflavin penetration. Currently, there are a number of studies looking into riboflavin penetration with epithelium intact and how this may improve CXL [163,165,167,174-178]. These have been previously reviewed and will not be discussed here [163]. Overall, CXL is a promising technique to arrest the disease, but we still lack long-term data [167-174]. 
Figure 4. Application of riboflavin drops during corneal cross linking procedure.

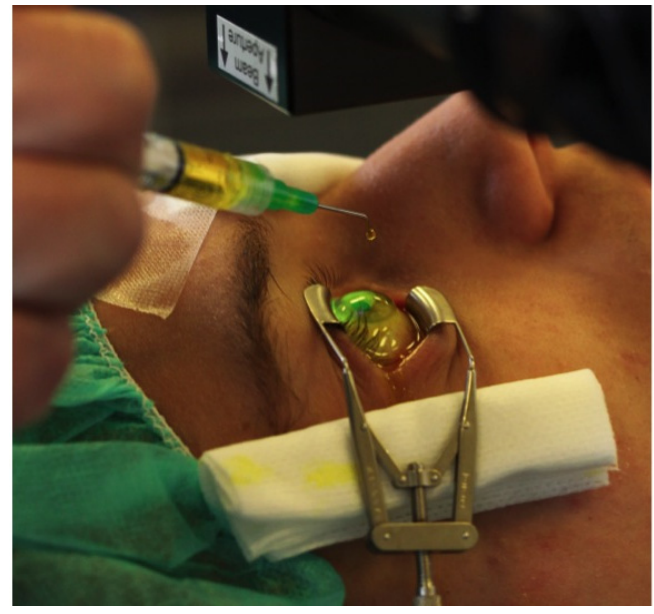

\section{In Vitro Strategies}

The World Health Organization (WHO) reported that corneal diseases are a major cause of vision loss and blindness, second only to cataracts in overall importance [10]. The only acceptable method for treating corneal blindness is by transplantation with matched donor tissue. It is easily understood that the demand for donor corneas exceeds the supply and therefore other strategies have been studied. One of them is in vitro models. Can corneas be grown in the lab from human cells and then be transplanted to a patient with trauma or blindness? Despite recent advancements in designing those tissues in vitro, there are very few that have come close. This is not a surprise, considering the complex nature of the corneal tissue. An in vitro tissue would have to have at least the stromal layer in place, if not the stroma and epithelium, the right thickness, with the correct organization, immune properties, and optical characteristics. Of the models developed so far, probably the most promising was the model by the Laboratoire d'Organogenese Experimentale (LOEX) [3,6]. The authors used the self-assembly approach where cells were stimulated with ascorbic acid to induce ECM production. They were able to stack multiples of those 3D ECMs and seed an epithelium on top and an endothelium at the bottom. This was well received with good tensile strength, but no optical data was reported [3,6]. In KC, an approach like this would not be necessary since the endothelium normally remains intact and what needs to be restored are the stroma and/or epithelium. In a recent study, corneal stromal cells derived from $\mathrm{KC}$ donors were isolated and stimulated with ascorbic acid [4] in order to characterize ECM secretion and assembly. The authors reported major differences from healthy corneal cells including the inability to secrete large amounts of ECM, higher number of myofibroblasts, and fibrotic ECM [4]. This confirmed the dysfunction of $\mathrm{KC}$ stromal cells and the need for replacement or reprogramming. It is therefore clear that the $3 \mathrm{D}$ in vitro models hold great potential for $\mathrm{KC}$ transplantation, but more refinement and studies are necessary before those can be transplanted. Other in vitro models of $\mathrm{KC}$ disease are concentrating on 2D studies and cell-cell interactions [2,5-9,11-16]. While these are invaluable and provide a better understanding on mechanism, the more clinically oriented models are the ones that can possibly provide a future treatment of the $\mathrm{KC}$ defects. 


\section{Tissue Engineering Materials}

Tissue engineering strategies have been very important in a variety of therapeutic approaches [179-184]. The ultimate goal is to repair or replace portions or whole tissues using these strategies. KC is a corneal dystrophy that currently lacks animal model for detailed studies and interestingly enough not many tissue engineering strategies have been attempted. It is important to keep in mind a few rules about using tissue engineering solutions for corneal tissue. An artificial cornea would have to adhere to several basic rules in order to be successful. (1) Integrate into the recipient tissue and the surroundings, (2) allow epithelial layer formation and tear film, (3) allow corneal innervation without side effects, (4) avoid immunologic reactions and infections, and (5) adopt corneal functions such as optical refraction. The next section of this review will discuss some of the most popular and widely used biomaterials that can be important for KC treatment.

\subsection{Acellular Corneal Stroma}

The most successful and widely accepted treatment for $\mathrm{KC}$ is corneal transplantation where the damaged tissue is replaced with a human donor cornea. While this is popular, there are a several limitations as discussed above. Recently, developments in bioengineered corneal substitutes have been designed, including acellular matrices [185-191]. Corneal ECM is mainly collagenous and the obvious choice would be an acellular collagen ECM which can be successfully implanted. This has been developed and tested mainly in animals $[187,188,191,192]$ where the ACS relies on repopulation by host cells to restore corneal function and therefore vision. Griffith and co-authors reported ACS transplantation in humans [193] with the highest corrected visual acuity of 0.4 achieved. However, there were problems with these constructs, such as post-surgical astigmatism developed by $60 \%$ of the patients due to degradation of the biomaterial. Fish-scale collagen ECM is a different type of ACS and it has only been recently investigated in ocular research [194-198]. Briefly, it is a naturally occurring collagen Type I obtained from scales of the tilapia fish. Their scales consist of highly organized, parallel arranged collagen fibers that are packed in layers oriented approximately 90 degrees, mirroring a human cornea [194-196]. It has been shown that this ECM can support the growth of corneal cells in vitro with high levels of oxygen permeability [197]. In addition, the fish-scale ECM is shown to have minimum inflammatory responses in vivo [198]. Recently, van Essen and co-authors [194] reported promising results when the fish-scale ECM was used in a rat anterior lamellar keratoplasty. One of the latest technologies is the supramolecular 4-arm-PEG-(POG) biomaterial which shows great promise as a drug carrier in corneal diseases and defects [199]. While the ACS solution is by no means ready, it represents an interesting option for $\mathrm{KC}$ patients that require transplantation. With a shortage of corneal donor tissue it is vital that we consider alternative solutions.

\subsection{Collagen Equivalents}

There is a huge variety of collagen models for corneal applications. Collagen has been used for years in many applications and holds great potential for many diseases. In $\mathrm{KC}$, it is obvious to consider a partial transplantation with a collagen ECM. Here, we review some of the most promising systems available that might help in the $\mathrm{KC}$ treatment in the future. In its simplest form, a cornea equivalent 
consists of a collagen stromal ECM with corneal keratocytes seeded in it and covered with an epithelium layer [200-203]. Parnigotto et al. [201] mixed keratocytes with collagen extracted from rat tails and seeded a layer of epithelial cells on top, letting the co-culture grow for 7 days. The results showed a good epithelial layer with expression of known differentiation markers such as AE5. Germain [202,203] constructed a corneal equivalent with 4-5 layers of epithelium following culture for 3 days on top of collagen ECM with keratocytes. In that study, staining of anti-integrin $\beta 1$ was shown in the basal cells, mimicking normal corneas in vivo. Other integrins reported included $\alpha 3, \alpha 5$, and $\alpha 6$. As an alternative to the rat tail collagen ECM, Orwin and Hubel [200] developed a co-culture model using bovine Type I dermal collagen. In that study, both epithelial-stroma and endothelial-stroma equivalents were reported.

As natural development, several attempts have been made to develop a more reliable corneal equivalent that mimics the entire human cornea in vivo and consist of all layers: corneal epithelium, stroma, and endothelium. So far, three-dimensional corneal equivalents with primary bovine corneal cells [204-206], primary rabbit corneal epithelial and endothelial cells, immortalized mouse corneal endothelial cells [207], primary corneal pig cell [208-211], primary human corneal epithelial cells and fibroblasts, immortalized human endothelial cells [212], and immortalized human corneal cell lines [213-215] have been reported. Whole corneal replacement is not necessary for $\mathrm{KC}$ treatment, and almost certainly an epithelium-stroma co-cultured ECM is the most likely target for KC transplantation. If developed, this could provide ways for treating $\mathrm{KC}$ defects and at least partially replace corneal transplantation. Clearly, there are questions about the viability of the constructs, such as survival of the cells once transplanted, cell type to be transplanted, cell source, and graft failure. These are only a few of the concerns that need to be addressed before a clear solution can be found.

\subsection{Polymers}

The ECM is a critical part of every tissue/organ and it provides physical support to tissues and defines cellular behaviors and tissue functions. The other popular approach in tissue engineering is the use of polymers. There are two main categories: biopolymers and synthetic polymers [216]. The main difference between the two is in their structure [217]. Biopolymers are polymers produced by living organisms and their structures are predetermined based on their physical characteristics [216,218,219]. On the other hand, the synthetic polymers are human-made and their properties are well controlled [217,220]. They have superior mechanical and physical properties and because they are human-made, are easy to produce in large batches and maintain reproducibility. The problem with them is that they tend to lack biocompatibility and therefore result in inflammatory responses, rejections by the host, and fibrosis. In cornea, the most well-known synthetic product is keratoprostheses (KPros) [221-227] which are designed to replace the central portion of an opaque cornea. KPros have been used for many years with relatively high success rates. A recent alternative has been the AlphaCor [228-230]. AlphCor is a transparent poly9hydroxyethyl methacrylate (pHEMA) sponge that allows cellular ingrowth. While this is a promising polymer, and it could potentially be used for KC treatment to replace cornea thickness and allow cell migration, there are significant problems, such as the non-existing re-epithelialization and nerve regeneration. Perhaps, the most promising report of polymers with adequate transparency for corneal repair and good cell ingrowth are from Bruinning et al. [231] who 
reported a free-radical polymerization of butyl methacrylate, hexaethyleneglycolmethacrylate, and a dimethacrylate cross-linker.

In human cornea application, the most dominant biopolymers are collagen I and collagen V, which are the base of most bioscaffolds developed today. Griffith et al. [232,233] fabricated stromal ECM from glutaraldehyde cross linked collagen/chondroitin-6-sulfate hydrogels. The authors reported acceptable morphological characteristics; however, the physical properties of the material were inadequate for transplantation. As an improvement to their original model, the authors later reported a terpolymer named $\operatorname{poly}(\mathrm{N}$-isopropylacrylamide-co-acrylic acid-co-acryloxysuccinimide) or PNiPAAm-co-AAc-co-ASI [187,234]. These resulting hydrogels were adequate for transplantation and when tested in pigs, allowed epithelial overgrowth, stromal cell ingrowth, and functional nerve plexus [187].

\section{Future}

Biomaterials are expected by scientists to function as cell scaffolds to replace damaged or injured tissue/organ. The composition and properties of biomaterials used for tissue engineering varies significantly between individuals and tissues. Ultimately, the goal is to replace or regenerate the damaged tissue without any complications for the host. In the cornea, the major challenge is to replace and maintain the transparency properties of the original tissue. The complex structure of a dense and highly organized collagen ECM in the human cornea is a challenge for biomaterials. In $\mathrm{KC}$, there are three main characteristics of the disease: (1) cornea thinning, (2) corneal bulging, and (3) corneal scarring. In order to apply tissue engineering techniques, there are several characteristics that the new biomaterial should provide. It should have similar mechanical and physical properties to the host tissue, replaces the stroma thickness while it allows for host keratocytes to migrate and repopulate it, and at the same time be friendly to the epithelial cells so they can grow on top of the graft. Of course, cell-seeded biomaterials are also possible and could be transplanted with keratocytes and epithelial cells. In this case, the main challenge would be to avoid graft rejection and any immunological responses by the host tissue. Conventional biomaterials are designed and fabricated relatively easily these days and have found applications in a variety of tissues. One of the most popular collagen-based ones is the animal-derived collagen and poly(glycolic acid) (PGA). Despite the progress, however, further refinement of current biotechnology and tissue engineering techniques is necessary. In order for our biomaterials to mimic the native tissue or organ at the nanoscale level and be able to provide biocompatibility, further more intelligent biomaterial development is necessary. In $\mathrm{KC}$ and in any ocular trauma defect, such a biomaterial would instantly find space in surgical rooms. Being able to restore vision is vital for quality of life. Corneal transplants are currently available and have great success; however, the cornea donor shortage is a major problem. This is especially true for third world countries or places where they do not have access to these tissues due to legislation, logistics, or religion.

One area of research that remains to be explored further is the area of embryonic stem cells (ESC). Whether we are talking about injecting these cells or combining them with a substrate for transplantation, these cells have properties that can be proven vital in tissue engineering advancements. In KC, stem cells have not been employed or tested yet. Can these cells differentiate to keratocytes? Can they repair the lost corneal thickness? Can they restore its physical properties? Can they do it on their own or is a substrate is required? If yes, which substrate is the best for these cells to thrive? Autogenous ESCs would 
be ideal in order to minimize chances of host rejection and immune responses; however, this is not always available due to harvesting techniques and phenotype control. Use of xenogeneic or allogeneic cells requires even more attention since it is vital to shut down immunological avenues before transplantation.

Still, great interest and potential remains for developing new, "smart" biomaterials that can be used with or without cells as implants to stimulate and enhance regeneration. Based on the composition of the cornea, the obvious choice of a biomaterial would be collagen based. However, any advancement would be well-received in combination or with modifications for promoting corneal regeneration.

\section{Conclusions}

The systematic study of the physical and biochemical effects and capabilities of the available biomaterials as corneal replacement demonstrates their potential for future use in $\mathrm{KC}$ disease as well as in other corneal defects. The availability of an easy obtainable, cost-effective, and biocompatible biomaterial can have a high impact on treating $\mathrm{KC}$ and reduce the shortage of donor corneas. The arrival of CXL has definitely changed the KC treatment standards; however, there is still a large number of people that will require corneal transplantation and can benefit from the development of a biomaterial.

\section{Acknowledgments}

We would like to thank the National Institutes of Health and National Eye Institute for their financial support (R01-EY023568).

\section{Author Contributions}

D.K. and J.H. contributed equally to this manuscript; D.K and J.H. wrote the article.

\section{Conflicts of Interest}

The authors declare no conflict of interest.

\section{References}

1. Jensen, L.B.; Hjortdal, J.; Ehlers, N. Longterm follow-up of penetrating keratoplasty for keratoconus. Acta Ophthalmol. 2010, 88, 347-351.

2. Nielsen, K.; Hjortdal, J.; Aagaard Nohr, E.; Ehlers, N. Incidence and prevalence of keratoconus in denmark. Acta Ophthalmol. Scand. 2007, 85, 890-892.

3. Rabinowitz, Y.S. Keratoconus. Surv. Ophthalmol. 1998, 42, 297-319.

4. Zadnik, K.; Barr, J.T.; Edrington, T.B.; Everett, D.F.; Jameson, M.; McMahon, T.T.; Shin, J.A.; Sterling, J.L.; Wagner, H.; Gordon, M.O. Baseline findings in the collaborative longitudinal evaluation of keratoconus (clek) study. Investig. Ophthalmol. Vis. Sci. 1998, 39, 2537-2546.

5. Owens, H.; Gamble, G. A profile of keratoconus in New Zealand. Cornea 2003, 22, 122-125.

6. Grunauer-Kloevekorn, C.; Duncker, G.I. Keratoconus: Epidemiology, risk factors and diagnosis. Klin. Monbl. Augenheilkd 2006, 223, 493-502. 
7. Georgiou, T.; Funnell, C.L.; Cassels-Brown, A.; O’Conor, R. Influence of ethnic origin on the incidence of keratoconus and associated atopic disease in asians and white patients. Eye 2004, 18, 379-383.

8. McGhee, C.N. 2008 sir norman mcalister gregg lecture: 150 years of practical observations on the conical cornea-What have we learned? Clin. Exp. Ophthalmol. 2009, 37, 160-176.

9. Kennedy, R.H.; Bourne, W.M.; Dyer, J.A. A 48-year clinical and epidemiologic study of keratoconus. Am. J. Ophthalmol. 1986, 101, 267-273.

10. Tan, B.; Baker, K.; Chen, Y.L.; Lewis, J.W.L.; Shi, L.; Swartz, T.; Wang, M. How keratoconus influences optical performance of the eye. J. Vis. 2008, 8, 1-10.

11. Karamichos, D. Keratoconus: In vitro and in vivo. Clin. J. Ophthalmol. 2014, 1, 2.

12. Cingu, A.K.; Cinar, Y.; Turkcu, F.M.; Sahin, A.; Ari, S.; Yuksel, H.; Sahin, M.; Caca, I. Effects of vernal and allergic conjunctivitis on severity of keratoconus. Int. J. Ophthalmol. 2013, 6, 370-374.

13. Colby, K.; Dohlman, C. Vernal keratoconjunctivitis. Int. Ophthalmol. Clin. 1996, 36, 15-20.

14. Chaerkady, R.; Shao, H.; Scott, S.G.; Pandey, A.; Jun, A.S.; Chakravarti, S. The keratoconus corneal proteome: Loss of epithelial integrity and stromal degeneration. J. Proteomics 2013, 87, $122-131$.

15. Contact lenses for Keratoconus. National Keratoconus Foundation Website. Available online: http://www.nkcf.org/contact-lenses-for-kc/ (accessed on 5 September 2014).

16. Vazirani, J.; Basu, S. Keratoconus: Current perspectives. Clin. Ophthalmol. 2013, 7, 2019-2030.

17. Karamichos, D.; Zareian, R.; Guo, X.; Hutcheon, A.E.; Ruberti, J.W.; Zieske, J.D. Novel in vitro model for keratoconus disease. J. Funct. Biomater. 2012, 3, 760-775.

18. Kenney, M.C.; Chwa, M.; Escobar, M.; Brown, D.J. Altered gelatinolytic activity by keratoconus corneal cells. Biochem. Biophys. Res. Commun. 1989, 161, 353-357.

19. Sharma, M.; Boxer Wachler, B.S. Comparison of single-segment and double-segment intacs for keratoconus and post-lasik ectasia. Am. J. Ophthalmol. 2006, 141, 891-895.

20. Feder, R.; Kshettry, P. Non-inflammatory ectactic disorders. In Cornea; Krachmer, J., Ed.; Elsevier: Philadelphia, PA, USA, 2005.

21. Vinciguerra, P.; Epstein, D.; Albè, E.; Spada, F.; Incarnato, N.; Orzalesi, N.; Rosetta, P. Corneal topography-guided penetrating keratoplasty and suture adjustment: New approach for astigmatism control. Cornea 2007, 26, 675-682.

22. Pantanelli, S.; MacRae, S.; Jeong, T.M.; Yoon, G. Characterizing the wave aberration in eyes with keratoconus or penetrating keratoplasty using a high-dynamic range wavefront sensor. Ophthalmology 2007, 114, 2013-2021.

23. Nakagawa, T.; Maeda, N.; Kosaki, R.; Hori, Y.; Inoue, T.; Saika, M.; Mihashi, T.; Fujikado, T.; Tano, Y. Higher-order aberrations due to the posterior corneal surface in patients with keratoconus. Investig. Ophthalmol. Vis. Sci. 2009, 50, 2660-2665.

24. Tian, C.; Peng, X.; Fan, Z.; Zhang, X.; Zhou, F. Corneal collagen cross-linking in keratoconus: A systematic review and meta-analysis. Sci. Rep. 2014, 4, doi:10.1038/srep05652.

25. O’Brart, D.P. Corneal collagen cross-linking: A review. J. Optom. 2014, 7, 113-124. 
26. Craig, J.A.; Mahon, J.; Yellowlees, A.; Barata, T.; Glanville, J.; Arber, M.; Mandava, L.; Powell, J.; Figueiredo, F. Epithelium-off photochemical corneal collagen cross-linkage using riboflavin and ultraviolet a for keratoconus and keratectasia: A systematic review and meta-analysis. Ocul. Surf. 2014, 12, 202-214.

27. Girard, M.J.; Dupps, W.J.; Baskaran, M.; Scarcelli, G.; Yun, S.H.; Quigley, H.A.; Sigal, I.A.; Strouthidis, N.G. Translating ocular biomechanics into clinical practice: Current state and future prospects. Curr. Eye Res. 2014, doi:10.3109/02713683.2014.914543.

28. Sorkin, N.; Varssano, D. Corneal collagen crosslinking: A systematic review. Ophthalmologica 2014, 232, 10-27.

29. Romero-Jimenez, M.; Santodomingo-Rubido, J.; Wolffsohn, J.S. Keratoconus: A review. Contact Lens Anterior Eye 2010, 33, 157-166.

30. Wojcik, K.A.; Kaminska, A.; Blasiak, J.; Szaflik, J.; Szaflik, J.P. Oxidative stress in the pathogenesis of keratoconus and fuchs endothelial corneal dystrophy. Int. J. Mol. Sci. 2013, 14, 19294-19308.

31. Kanellopoulos, A.J. Comparison of sequential vs. same-day simultaneous collagen cross-linking and topography-guided PRK for treatment of keratoconus. J. Refract. Surg. 2009, 25, S812-S818.

32. Wittig-Silva, C.; Whiting, M.; Lamoureux, E.; Lindsay, R.G.; Sullivan, L.J.; Snibson, G.R. A randomized controlled trial of corneal collagen cross-linking in progressive keratoconus: Preliminary results. J. Refract. Surg. 2008, 24, S720-S725.

33. Boxer Wachler, B.S. Corneal crosslinking with riboflavin. A new treatment to strengthen the cornea for keratoectasia and keratoconus. Cataract Refract. Surg. Today 2005, 73-74.

34. Hasson, M. FDA backs launch of collagen cross-linking clinical trials. Ocular Surgery News 25 January 2018.

35. Avedro Becomes Sponsor of US FDA Clinical Trials of Corneal Collagen Crosslinking. Business Wire Website. Available online: http:/www.businesswire.com/news/home/20100316006968/en/ Avedro-Sponsor-FDA-Clinical-Trials-Corneal-Collagen (accessed on 5 September 2014).

36. Rabinowitz, Y.S.; Garbus, J.; McDonnell, P.J. Computer-assisted corneal topography in family members of patients with keratoconus. Arch. Ophthalmol. 1990, 108, 365-371.

37. Falls, H.F.; Allen, A.W. Dominantly inherited keratoconus-Report of a family. J. Genetique Hum. 1969, 17, 317-324.

38. Redmond, K.B. The role of heredity in keratoconus. Trans. Ophthalmol. Soc. Aust. 1968, 27, 52-54.

39. Rabinowitz, Y.S.; Nesburn, A.B.; McDonnell, P.J. Videokeratography of the fellow eye in unilateral keratoconus. Ophthalmology 1993, 100, 181-186.

40. Krachmer, J.H.; Feder, R.S.; Belin, M.W. Keratoconus and related noninflammatory corneal thinning disorders. Surv. Ophthalmol. 1984, 28, 293-322.

41. Bleckmann, H.; Kresse, H. Studies on the glycosaminoglycan metabolism of cultured fibroblasts from human keratoconus corneas. Exp. Eye Res. 1980, 30, 215-219.

42. Meek, K.M.; Elliott, G.F.; Gyi, T.J.; Wall, R.S. The structure of normal and keratoconus human corneas. Ophthalmic Res. 1987, 19, 6-7.

43. Kao, W.W.; Vergnes, J.P.; Ebert, J.; Sundar-Raj, C.V.; Brown, S.I. Increased collagenase and gelatinase activities in keratoconus. Biochem. Biophys. Res. Commun. 1982, 107, 929-936. 
44. Rehany, U.; Lahav, M.; Shoshan, S. Collagenolytic activity in keratoconus. Ann. Ophthalmol. 1982, 14, 751-754.

45. Cannon, D.J.; Foster, C.S. Collagen crosslinking in keratoconus. Investig. Ophthalmol. Vis. Sci. 1978, 171, 63-65.

46. Austin, M.G.; Schaefer, R.F. Marfan's syndrome, with unusual blood vessel manifestations. A.M.A. Arch. Pathol. 1957, 64, 205-209.

47. Judisch, G.F.; Waziri, M.; Krachmer, J.H. Ocular ehlers-danlos syndrome with normal lysyl hydroxylase activity. Arch. Ophthalmol. 1976, 94, 1489-1491.

48. Meek, K.M.; Tuft, S.J.; Huang, Y.; Gill, P.S.; Hayes, S.; Newton, R.H.; Bron, A.J. Changes in collagen orientation and distribution in keratoconus corneas. Investig. Ophthalmol. Vis. Sci. 2005, 46, 1948-1956.

49. Hayes, S.; Khan, S.; Boote, C.; Kamma-Lorger, C.S.; Dooley, E.; Lewis, J.; Hawksworth, N.; Sorensen, T.; Daya, S.; Meek, K.M. Depth profile study of abnormal collagen orientation in keratoconus corneas. Arch. Ophthalmol. 2012, 130, 251-252.

50. Donnenfeld, E.D.; Kanellopoulos, A.J.; Perry, H.D. Keratoconus: Advances in diagnosis, etiology and treatment. Laser Vison Website. Available online: http://www.laservision.gr/en/ $\% \mathrm{CE} \% \mathrm{~B} 5 \% \mathrm{CF} \% 80 \% \mathrm{CE} \% \mathrm{~B} 5 \% \mathrm{CE} \% \mathrm{BC} \% \mathrm{CE} \% \mathrm{~B} 2 \% \mathrm{CE} \% \mathrm{AC} \% \mathrm{CF} \% 83 \% \mathrm{CE} \% \mathrm{~B} 5 \% \mathrm{CE} \% \mathrm{~B} 9 \% \mathrm{CF}$ $\% 82 / \% \mathrm{CE} \% \mathrm{BA} \% \mathrm{CE} \% \mathrm{~B} 5 \% \mathrm{CF} \% 81 \% \mathrm{CE} \% \mathrm{~B} 1 \% \mathrm{CF} \% 84 \% \mathrm{CE} \% \mathrm{BF} \% \mathrm{CE} \% \mathrm{~B} 5 \% \mathrm{CE} \% \mathrm{~B} 9 \% \mathrm{CE} \% \mathrm{~B} 4$ $\% \mathrm{CE} \% \mathrm{AE} \% \mathrm{CF} \% 82 /$ english-keratoconus-advances-in-diagnosis-etiology-and-treatment (accessed on 5 September 2014).

51. Alstrom, C.H.; Olson, O. Heredo-retinopathia congenitalis. Monohybride recessiva autosomalis. Hered. Genttiskt 1957, 43, 1-177.

52. Cullen, J.F.; Butler, H.G. Mongolism (down's syndrome) and keratoconus. Br. J. Ophthalmol. 1963, 47, 321-330.

53. Shapiro, M.B.; France, T.D. The ocular features of down's syndrome. Am. J. Ophthalmol. 1985, 99, 659-663.

54. Tretter, T.; Rabinowitz, Y.S.; Yang, H. Aetiological factors in keratoconus. Ophthalmology 1995, 102,156.

55. Nielsen, K.; Hjortdal, J.; Pihlmann, M.; Corydon, T.J. Update on the keratoconus genetics. Acta Ophthalmol. 2013, 91, 106-113.

56. Gordon-Shaag, A.; Millodot, M.; Shneor, E. The epidemiology and etiology of keratoconus. Int. J. Keratoconus Ectatic Corneal Dis. 2012, 1, 7-15.

57. Ertan, A.; Muftuoglu, O. Keratoconus clinical findings according to different age and gender groups. Cornea 2008, 27, 1109-1113.

58. Millodot, M.; Shneor, E.; Albou, S.; Atlani, E.; Gordon-Shaag, A. Prevalence and associated factors of keratoconus in jerusalem: A cross-sectional study. Ophthalmic Epidemiol. 2011, 18, 91-97.

59. Bawazeer, A.M.; Hodge, W.G.; Lorimer, B. Atopy and keratoconus: A multivariate analysis. $\mathrm{Br}$. J. Ophthalmol. 2000, 84, 834-836.

60. Ljubic, A.D. Keratoconus and its prevalence in macedonia. Maced. J. Med. Sci. 2009, 2, 58-62.

61. Pearson, A.R.; Soneji, B.; Sarvananthan, N.; Sandford-Smith, J.H. Does ethnic origin influence the incidence or severity of keratoconus? Eye 2000, 14, 625-628. 
62. Wang, Y.; Rabinowitz, Y.S.; Rotter, J.I.; Yang, H. Genetic epidemiological study of keratoconus: Evidence for major gene determination. Am. J. Med. Genet. 2000, 93, 403-409.

63. Weed, K.H.; MacEwen, C.J.; Giles, T.; Low, J.; McGhee, C.N. The dundee university scottish keratoconus study: Demographics, corneal signs, associated diseases, and eye rubbing. Eye 2008, 22, 534-541.

64. Koenig, S.B. Bilateral recurrent self-induced keratoconus. Eye Contact Lens 2008, 34, 343-344.

65. McMonnies, C.W.; Boneham, G.C. Keratoconus, allergy, itch, eye-rubbing and hand-dominance. Clin. Exp. Optom. 2003, 86, 376-384.

66. Jafri, B.; Lichter, H.; Stulting, R.D. Asymmetric keratoconus attributed to eye rubbing. Cornea 2004, 23, 560-564.

67. Ioannidis, A.S.; Speedwell, L.; Nischal, K.K. Unilateral keratoconus in a child with chronic and persistent eye rubbing. Am. J. Ophthalmol. 2005, 139, 356-357.

68. Lindsay, R.G.; Bruce, A.S.; Gutteridge, I.F. Keratoconus associated with continual eye rubbing due to punctal agenesis. Cornea 2000, 19, 567-569.

69. Ridley, F. Scleral contact lenses in keratoconus. In Contact Lenses: Symposium in Munich-Feldafing; Dabezies, O., Ed.; Karger: Basel, Switzerland, 1967; pp. 163-173.

70. Karseras, A.G.; Ruben, M. Aetiology of keratoconus. Br. J. Ophthalmol. 1976, 60, 522-525.

71. Brightbill, F.S.; Stainer, G.A. Previous hard contact lens wear in keratoconus. Contact Intraocular Lenses Med. J. 1979, 5, 43-46.

72. Mannis, M.J.; Zadnik, K. Contact lens fitting in keratoconus. Eye Contact Lens 1989, 15, 282-289.

73. Fowler, W.C.; Belin, M.W.; Chambers, W.A. Contact lenses in the visual correction of keratoconus. Eye Contact Lens 1988, 14, 203-206.

74. Karamichos, D.; Hutcheon, A.E.; Rich, C.B.; Trinkaus-Randall, V.; Asara, J.M.; Zieske, J.D. In vitro model suggests oxidative stress involved in keratoconus disease. Sci. Rep. 2014, 4, doi:10.1038/srep04608.

75. Kenney, M.C.; Brown, D.J.; Rajeev, B. Everett Kinsey lecture. The elusive causes of keratoconus: A working hypothesis. CLAO J. 2000, 26, 10-13.

76. Greiner, J.V.; Kopp, S.J.; Glonek, T. Phosphorus nuclear magnetic resonance and ocular metabolism. Surv. Ophthalmol. 1985, 30, 189-202.

77. Risa, O.; Saether, O.; Lofgren, S.; Soderberg, P.G.; Krane, J.; Midelfart, A. Metabolic changes in rat lens after in vivo exposure to ultraviolet irradiation: Measurements by high resolution MAS ${ }^{1} \mathrm{H}$ NMR spectroscopy. Investig. Ophthalmol. Vis. Sci. 2004, 45, 1916-1921.

78. Holland, E.J.; Mannis, M.J. Ocular Surface Disease Medical and surgical management. In Grayson's Diseases of the Cornea; Holland, E.J.; Mannis M.J., Eds.; Springer: New York, NY, USA, 2001.

79. Corneal dystrophies. Royal National Institute of Blind People Website. Available online: http://www.rnib.org.uk/eye-health-eye-conditions-z-eye-conditions/corneal-dystrophies (accessed on 5 September 2014).

80. Rubinstein, M.P.; Sud, S. The use of hybrid lenses in management of the irregular cornea. Contact Lens Anterior Eye 1999, 22, 87-90. 
81. Carracedo, G.; González-Méijome, J.M.; Lopes-Ferreira, D.; Carballo, J.; Batres, L. Clinical performance of a new hybrid contact lens for keratoconus. Eye Contact Lens 2014 40, 2-6.

82. Rathi, V.M.; Mandathara, P.S.; Dumpati, S. Contact lens in keratoconus. Indian J. Ophthalmol. 2013, 61, 410-415.

83. Downie, L.E. Predictive value of corneal topography for ClearKone hybrid contact lenses. Optom. Vis. Sci. 2013, 90, 191-197.

84. Yanoff, M.; Duker, J. Ophthalmology, 2nd ed.; Mosby: St. Louis, Mo, USA, 2004; pp. 315-325.

85. INTACS ${ }^{\circledR}$ Prescription Inserts for Keratoconus. U.S. Food and Drug Administration Website. Available online: http://www.fda.gov/MedicalDevices/ProductsandMedicalProcedures/Device ApprovalsandClearances/Recently-ApprovedDevices/ucm080953.htm (accessed on 5 September 2014).

86. Jorge, L.A. Keratoconus treatment. Ophthalmol. Times Eur. 2013, 9, Available online: http://www.oteurope.com/ophthalmologytimeseurope/CatRef+features/Keratoconus-treatment/ ArticleStandard/Article/detail/820252 (accessed on 5 September 2014).

87. New Humanitarian Device Approval INTACS ${ }^{\circledR}$ Prescription Inserts for Keratoconus Services. Available online: http://www.accessdata.fda.gov/cdrh_docs/pdf4/h040002a.pdf (accessed on 5 September 2014).

88. Keraflex Clinical Trial Starts in the US. National Keratoconus Foundation Wetsite. Available online: http://www.nkcf.org/keraflex-kxl/ (accessed on 5 September 2014).

89. Vega-Estrada, A.; Alio, J.L.; Plaza Puche, A.B.; Marshall, J. Outcomes of a new microwave procedure followed by accelerated cross-linking for the treatment of keratoconus: A pilot study. J. Refract. Surg. 2012, 28, 787-793.

90. Keraflex Treatment for Keratoconus; Istituto Laser Microchirurgia Oculare Website. Available online: http://www.ilmo.it/en/solutions/surgery-at-ilmo/keraflex-for-keratoconus (accessed on 5 September 2014).

91. Jabbur, N.S.; Stark, W.J.; Green, W.R. Corneal ectasia after laser-assisted in situ keratomileusis. Arch. Ophthalmol. 2001, 119, 1714-1716.

92. Colin, J.; Velou, S. Current surgical options for keratoconus. J. Cataract Refract. Surg. 2003, 29, 379-386.

93. Bergmanson, J.P.; Farmer, E.J. A return to primitive practice? Radial keratotomy revisited. Contact Lens Anterior Eye 1999, 22, 2-10.

94. Lombardi, M.; Abbondanza, M. Asymmetric radial keratotomy for the correction of keratoconus. J. Refract. Surg. 1997, 13, 302-307.

95. Mini ark surgery: Modified Asymmetric Radial Keratomy known as Mini ARK Surgery. Lombardi Clinic Website. Available online: http://www.lombardieyeclinic.com/keratoconus/mini-arksurgery.htm (accessed on 5 September 2014).

96. Sab, F.D. La curva pericolosa della cornea. Available online: http://www.ilgiornale.it/news/ curva-pericolosa-cornea.html (accessed on 5 September 2014).

97. Kohlhaas, M.; Draeger, J.; Bohm, A.; Lombardi, M.; Abbondanza, M.; Zuppardo, M.; Gorne, M. Aesthesiometry of the cornea after refractive corneal surgery. Klin. Monbl. Augenheilkd 1992, 201, 221-223. 
98. Refractive Changes Following CXL. Cataract and Refractive Surgery Today Website. Available online: http://bmctoday.net/crstodayeurope/2009/08/article.asp?f=0709_12.php (accessed on 5 September 2014).

99. Come curare il cheratocono a "Vivere meglio". Available online: http://www.mediaset.it/ quimediaset/comunicati/comunicato_3124.shtml (accessed on 5 September 2014).

100. Schirmbeck, T.; Paula, J.S.; Martin, L.F.; Crosio Filho, H.; Romao, E. Efficacy and low cost in keratoconus treatment with rigid gas-permeable contact lens. Arq. Bras. Oftalmol. 2005, 68, 219-222.

101. Javadi, M.A.; Motlagh, B.F.; Jafarinasab, M.R.; Rabbanikhah, Z.; Anissian, A.; Souri, H.; Yazdani, S. Outcomes of penetrating keratoplasty in keratoconus. Cornea 2005, 24, 941-946.

102. Sugita, J. Advances in Corneal Research: Selected Transactions of the World Congress on the Cornea IV; Springer: New York, NY, USA, 1997; pp. 163-166.

103. Wagoner, M.D.; Smith, S.D.; Rademaker, W.J.; Mahmood, M.A. Penetrating keratoplasty vs. Epikeratoplasty for the surgical treatment of keratoconus. J. Refract. Surg. 2001, 17, 138-146.

104. Brown, D. Research Overview. National Keratoconus Foundation Website. Available online: http://www.nkcf.org/keratoconus-research (accessed on 5 September 2014).

105. Mamalis, N.; Anderson, C.W.; Kreisler, K.R.; Lundergan, M.K.; Olson, R.J. Changing trends in the indications for penetrating keratoplasty. Arch. Ophthalmol. 1992, 110, 1409-1411.

106. Muraine, M.; Sanchez, C.; Watt, L.; Retout, A.; Brasseur, G. Long-term results of penetrating keratoplasty-A 10-year-plus retrospective study. Graef Arch. Clin. Exp. 2003, 241, 571-576.

107. Claesson, M.; Armitage, W.J. Ten-year follow-up of graft survival and visual outcome after penetrating keratoplasty in sweden. Cornea 2009, 28, 1124-1129.

108. Niziol, L.M.; Musch, D.C.; Gillespie, B.W.; Marcotte, L.M.; Sugar, A. Long-term outcomes in patients who received a corneal graft for keratoconus between 1980 and 1986. Am. J. Ophthalmol. 2013, 155, 213-219.

109. Choi, J.A.; Lee, M.A.; Kim, M.S. Long-term outcomes of penetrating keratoplasty in keratoconus: Analysis of the factors associated with final visual acuities. Int. J. Ophthalmol. 2014, 7, 517-521.

110. Lim, L.; Pesudovs, K.; Coster, D.J. Penetrating keratoplasty for keratoconus: Visual outcome and success. Ophthalmology 2000, 107, 1125-1131.

111. Keates, R.H.; Falkenstein, S. Keratoplasty in keratoconus. Am. J. Ophthalmol. 1972, 74, 442-444.

112. Troutman, R.C.; Lawless, M.A. Penetrating keratoplasty for keratoconus. Cornea 1987, 6, 298-305.

113. Kirkness, C.M.; Ficker, L.A.; Steele, A.D.; Rice, N.S. The success of penetrating keratoplasty for keratoconus. Eye 1990, 4, 673-688.

114. Epstein, R.J.; Seedor, J.A.; Dreizen, N.G.; Stulting, R.D.; Waring, G.O., III; Wilson, L.A.; Cavanagh, H.D. Penetrating keratoplasty for herpes simplex keratitis and keratoconus. Allograft rejection and survival. Ophthalmology 1987, 94, 935-944.

115. Chandler, J.W.; Kaufman, H.E. Graft reactions after keratoplasty for keratoconus. Am. J. Ophthalmol. 1974, 77, 543-547.

116. Malbran, E.S.; Fernandez-Meijide, R.E. Bilateral versus unilateral penetrating graft in keratoconus. Ophthalmology 1982, 89, 38-40. 
117. Ficker, L.A.; Kirkness, C.M.; Rice, N.S.; Steele, A.D. The changing management and improved prognosis for corneal grafting in herpes simplex keratitis. Ophthalmology 1989, 96, 1587-1596.

118. Melles, G.R.; Lander, F.; Rietveld, F.J.; Remeijer, L.; Beekhuis, W.H.; Binder, P.S. A new surgical technique for deep stromal, anterior lamellar keratoplasty. Br. J. Ophthalmol. 1999, 83, 327-333.

119. Fogla, R. Deep anterior lamellar keratoplasty in the management of keratoconus. Indian J. Ophthalmol. 2013, 61, 465-468.

120. Malbran, E.; Stefani, C. Lamellar keratoplasty in corneal ectasias. Ophthalmologica 1972, 164, $50-58$.

121. Price, F.W., Jr. Air lamellar keratoplasty. Refract. Corneal Surg. 1989, 5, 240-243.

122. Sugita, J.; Kondo, J. Deep lamellar keratoplasty with complete removal of pathological stroma for vision improvement. Br. J. Ophthalmol. 1997, 81, 184-188.

123. Edwards, M.; Clover, G.M.; Brookes, N.; Pendergrast, D.; Chaulk, J.; McGhee, C.N. Indications for corneal transplantation in New Zealand: 1991-1999. Cornea 2002, 21, 152-155.

124. Legeais, J.M.; Parc, C.; d'Hermies, F.; Pouliquen, Y.; Renard, G. Nineteen years of penetrating keratoplasty in the hotel-dieu hospital in paris. Cornea 2001, 20, 603-606.

125. Yahalom, C.; Mechoulam, H.; Solomon, A.; Raiskup, F.D.; Peer, J.; Frucht-Pery, J. Forty years of changing indications in penetrating keratoplasty in israel. Cornea 2005, 24, 256-258.

126. Kanavi, M.R.; Javadi, M.A.; Sanagoo, M. Indications for penetrating keratoplasty in iran. Cornea 2007, 26, 561-563.

127. Feizi, S.; Javadi, M.A.; Jamali, H.; Mirbabaee, F. Deep anterior lamellar keratoplasty in patients with keratoconus: Big-bubble technique. Cornea 2010, 29, 177-182.

128. Anwar, M.; Teichmann, K.D. Deep lamellar keratoplasty: Surgical techniques for anterior lamellar keratoplasty with and without baring of descemet's membrane. Cornea 2002, 21, 374-383.

129. Fogla, R.; Padmanabhan, P. Results of deep lamellar keratoplasty using the big-bubble technique in patients with keratoconus. Am. J. Ophthalmol. 2006, 141, 254-259.

130. Coombes, A.G.; Kirwan, J.F.; Rostron, C.K. Deep lamellar keratoplasty with lyophilised tissue in the management of keratoconus. Br. J. Ophthalmol. 2001, 85, 788-791.

131. Tsubota, K.; Kaido, M.; Monden, Y.; Satake, Y.; Bissen-Miyajima, H.; Shimazaki, J. A new surgical technique for deep lamellar keratoplasty with single running suture adjustment. Am. J. Ophthalmol. 1998, 126, 1-8.

132. Melles, G.R.; Remeijer, L.; Geerards, A.J.; Beekhuis, W.H. The future of lamellar keratoplasty. Curr. Opin. Ophthalmol. 1999, 10, 253-259.

133. Bhojwani, R.D.; Noble, B.; Chakrabarty, A.K.; Stewart, O.G. Sequestered viscoelastic after deep lamellar keratoplasty using viscodissection. Cornea 2003, 22, 371-373.

134. Kanavi, M.R.; Foroutan, A.R.; Kamel, M.R.; Afsar, N.; Javadi, M.A. Candida interface keratitis after deep anterior lamellar keratoplasty: Clinical, microbiologic, histopathologic, and confocal microscopic reports. Cornea 2007, 26, 913-916.

135. Colin, J. European clinical evaluation: Use of intacs for the treatment of keratoconus. J. Cataract Refract. Surg. 2006, 32, 747-755.

136. Schanzlin, D.J.; Asbell, P.A.; Burris, T.E.; Durrie, D.S. The intrastromal corneal ring segments. Phase ii results for the correction of myopia. Ophthalmology 1997, 104, 1067-1078. 
137. Nose, W.; Neves, R.A.; Burris, T.E.; Schanzlin, D.J.; Belfort Junior, R. Intrastromal corneal ring: 12-month sighted myopic eyes. J. Refract. Surg. 1996, 12, 20-28.

138. Fleming, J.F.; Wan, W.L.; Schanzlin, D.J. The theory of corneal curvature change with the intrastromal corneal ring. Eye Contact Lens 1989, 15, 146-150.

139. Cochener, B.; Le Floch, G.; Colin, J. Intra-corneal rings for the correction of weak myopias. J. Fr. Ophtalmol. 1998, 21, 191-208.

140. Asbell, P.A.; Ucakhan, O.O.; Durrie, D.S.; Lindstrom, R.L. Adjustability of refractive effect for corneal ring segments. J. Refract. Surg. 1999, 15, 627-631.

141. Burris, T.E.; Ayer, C.T.; Evensen, D.A.; Davenport, J.M. Effects of intrastromal corneal ring size and thickness on corneal flattening in human eyes. Refract. Corneal Surg. 1991, 7, 46-50.

142. Burris, T.E.; Baker, P.C.; Ayer, C.T.; Loomas, B.E.; Mathis, M.L.; Silvestrini, T.A. Flattening of central corneal curvature with intrastromal corneal rings of increasing thickness: An eye-bank eye study. J. Cataract Refract. Surg. 1993, 19, 182-187.

143. Shetty, R.; Kurian, M.; Anand, D.; Mhaske, P.; Narayana, K.M.; Shetty, B.K. Intacs in advanced keratoconus. Cornea 2008, 27, 1022-1029.

144. Ertan, A.; Ozkilic, E. Effect of age on outcomes in patients with keratoconus treated by intacs using a femtosecond laser. J. Refract.Surg. 2008, 24, 690-695.

145. Ertan, A.; Kamburoglu, G. Intacs implantation using a femtosecond laser for management of keratoconus: Comparison of 306 cases in different stages. J. Cataract Refract. Surg. 2008, 34, 1521-1526.

146. Shabayek, M.H.; Alio, J.L. Intrastromal corneal ring segment implantation by femtosecond laser for keratoconus correction. Ophthalmology 2007, 114, 1643-1652.

147. Zare, M.A.; Hashemi, H.; Salari, M.R. Intracorneal ring segment implantation for the management of keratoconus: Safety and efficacy. J. Cataract Refract. Surg. 2007, 33, 1886-1891.

148. Kymionis, G.D.; Siganos, C.S.; Tsiklis, N.S.; Anastasakis, A.; Yoo, S.H.; Pallikaris, A.I.; Astyrakakis, N.; Pallikaris, I.G. Long-term follow-up of intacs in keratoconus. Am. J. Ophthalmol. 2007, 143, 236-244.

149. Alio, J.L.; Shabayek, M.H.; Artola, A. Intracorneal ring segments for keratoconus correction: Long-term follow-up. J. Cataract Refract. Surg. 2006, 32, 978-985.

150. Alio, J.L.; Shabayek, M.H.; Belda, J.I.; Correas, P.; Feijoo, E.D. Analysis of results related to good and bad outcomes of intacs implantation for keratoconus correction. J. Cataract Refract. Surg. 2006, 32, 756-761.

151. Ertan, A.; Kamburoglu, G.; Bahadir, M. Intacs insertion with the femtosecond laser for the management of keratoconus: One-year results. J. Cataract Refract. Surg. 2006, 32, 2039-2042.

152. Kanellopoulos, A.J.; Pe, L.H.; Perry, H.D.; Donnenfeld, E.D. Modified intracorneal ring segment implantations (intacs) for the management of moderate to advanced keratoconus: Efficacy and complications. Cornea 2006, 25, 29-33.

153. Hellstedt, T.; Makela, J.; Uusitalo, R.; Emre, S.; Uusitalo, R. Treating keratoconus with intacs corneal ring segments. J. Refract. Surg. 2005, 21, 236-246.

154. Kwitko, S.; Severo, N.S. Ferrara intracorneal ring segments for keratoconus. J. Cataract Refract. Surg. 2004, 30, 812-820. 
155. Miranda, D.; Sartori, M.; Francesconi, C.; Allemann, N.; Ferrara, P.; Campos, M. Ferrara intrastromal corneal ring segments for severe keratoconus. J. Refract. Surg. 2003, 19, 645-653.

156. Siganos, C.S.; Kymionis, G.D.; Kartakis, N.; Theodorakis, M.A.; Astyrakakis, N.; Pallikaris, I.G. Management of keratoconus with intacs. Am. J. Ophthalmol. 2003, 135, 64-70.

157. Boxer Wachler, B.S.; Christie, J.P.; Chandra, N.S.; Chou, B.; Korn, T.; Nepomuceno, R. Intacs for keratoconus. Ophthalmology 2003, 110, 1031-1040.

158. Ruckhofer, J.; Stoiber, J.; Twa, M.D.; Grabner, G. Correction of astigmatism with short arc-length intrastromal corneal ring segments: Preliminary results. Ophthalmology 2003, 110, $516-524$.

159. Colin, J.; Cochener, B.; Savary, G.; Malet, F.; Holmes-Higgin, D. Intacs inserts for treating keratoconus: One-year results. Ophthalmology 2001, 108, 1409-1414.

160. Burris, T.E. Intrastromal corneal ring technology: Results and indications. Curr. Opin. Ophthalmol. 1998, 9, 9-14.

161. Colin, J.; Cochener, B.; Savary, G.; Malet, F. Correcting keratoconus with intracorneal rings. J. Cataract Refract. Surg. 2000, 26, 1117-1122.

162. Kamburoglu, G.; Ertan, A. Intacs implantation with sequential collagen cross-linking treatment in postoperative lasik ectasia. J. Refract. Surg. 2008, 24, S726-S729.

163. Meek, K.M.; Hayes, S. Corneal cross-linking-A review. Ophthalmic Physiol. Opt. J. Br. Coll. Ophthalmic Opt. 2013, 33, 78-93.

164. Abad, J.; Panesso, J. Corneal collagen cross-linking induced by UVA and riboflavin (CXL). Tech. Ophthalmol. 2008, 6, 8-12.

165. Baiocchi, S.; Mazzotta, C.; Cerretani, D.; Caporossi, T.; Caporossi, A. Corneal crosslinking: Riboflavin concentration in corneal stroma exposed with and without epithelium. J. Cataract Refract. Surg. 2009, 35, 893-899.

166. Samaras, K.E.; Lake, D.B. Corneal collagen cross linking (CXL): A review. Int. Ophthalmol. Clin. 2010, 50, 89-100.

167. Hayes, S.; Boote, C.; Kamma-Lorger, C.S.; Rajan, M.S.; Harris, J.; Dooley, E.; Hawksworth, N.; Hiller, J.; Terill, N.J.; Hafezi, F.; et al. Riboflavin/uva collagen cross-linking-induced changes in normal and keratoconus corneal stroma. PLoS One 2011, 6, doi:10.1371/journal.pone.0022405.

168. Koller, T.; Mrochen, M.; Seiler, T. Complication and failure rates after corneal crosslinking. J. Cataract Refract. Surg. 2009, 35, 1358-1362.

169. Caporossi, A.; Mazzotta, C.; Baiocchi, S.; Caporossi, T.; Denaro, R. Age-related long-term functional results after riboflavin UV a corneal cross-linking. J. Ophthalmol. 2011, 2011, doi:10.1155/2011/608041.

170. Raiskup-Wolf, F.; Hoyer, A.; Spoerl, E.; Pillunat, L.E. Collagen crosslinking with riboflavin and ultraviolet-a light in keratoconus: Long-term results. J. Cataract Refract. Surg. 2008, 34, 796-801.

171. Caporossi, A.; Baiocchi, S.; Mazzotta, C.; Traversi, C.; Caporossi, T. Parasurgical therapy for keratoconus by riboflavin-ultraviolet type a rays induced cross-linking of corneal collagen: Preliminary refractive results in an italian study. J. Cataract Refract. Surg. 2006, 32, 837-845. 
172. Coskunseven, E.; Jankov, M.R., II; Hafezi, F. Contralateral eye study of corneal collagen crosslinking with riboflavin and uva irradiation in patients with keratoconus. J. Refract. Surg. 2009, 25, 371-376.

173. Derakhshan, A.; Shandiz, J.H.; Ahadi, M.; Daneshvar, R.; Esmaily, H. Short-term outcomes of collagen crosslinking for early keratoconus. J. Ophthalmic Vis. Res. 2011, 6, 155-159.

174. Ivarsen, A.; Hjortdal, J. Collagen cross-linking for advanced progressive keratoconus. Cornea 2013, 32, 903-906.

175. Wollensak, G.; Iomdina, E. Biomechanical and histological changes after corneal crosslinking with and without epithelial debridement. J. Cataract Refract. Surg. 2009, 35, 540-546.

176. Yuen, L.; Chan, C.; Boxer Wachler, B.S. Effect of epithelial debridement in corneal collagen crosslinking therapy in porcine and human eyes. J. Cataract Refract. Surg. 2008, 34, 1815-1816.

177. Hatch, K.M. Corneal crosslinking: Epi-on or epi-off? In Program and abstracts of the American Society of Cataract and Refractive Surgery (ASCRS) 2012 Symposium on Cataract, IOL and Refractive Surgery, Chicago, IL, USA, 20-24 April 2012.

178. Leccisotti, A.; Islam, T. Transepithelial corneal collagen cross-linking in keratoconus. J. Refract. Surg. 2010, 26, 942-948.

179. Langer, R.; Vacanti, J.P. Tissue engineering. Science 1993, 260, 920-926.

180. MacArthur, B.D.; Oreffo, R.O. Bridging the gap. Nature 2005, 433, 19.

181. Whitney, G.A.; Mera, H.; Weidenbecher, M.; Awadallah, A.; Mansour, J.M.; Dennis, J.E. Methods for producing scaffold-free engineered cartilage sheets from auricular and articular chondrocyte cell sources and attachment to porous tantalum. BioRes. Open Access 2012, 1, 157-165.

182. Macchiarini, P.; Jungebluth, P.; Go, T.; Asnaghi, M.A.; Rees, L.E.; Cogan, T.A.; Dodson, A.; Martorell, J.; Bellini, S.; Parnigotto, P.P.; et al. Clinical transplantation of a tissue-engineered airway. Lancet 2008, 372, 2023-2030.

183. Zilla, P.; Greisler, H.P. Tissue engineering of vascular prosthetic grafts. Nat. Med. 1999, 5, doi:10.1038/13434.

184. Prestwich, G.D. Evaluating drug efficacy and toxicology in three dimensions: Using synthetic extracellular matrices in drug discovery. Accounts Chem. Res. 2008, 41, 139-148.

185. Myung, D.; Duhamel, P.E.; Cochran, J.R.; Noolandi, J.; Ta, C.N.; Frank, C.W. Development of hydrogel-based keratoprostheses: A materials perspective. Biotechnol. Progr. 2008, 24, 735-741.

186. Princz, M.A.; Sheardown, H.; Griffith, M. Corneal Tissue Engineering Versus Synthetic Artificial Corneas Inbiomaterials and Regenerative Medicine in Ophthalmology; CRC Press/Woodhead Publishing: Cambridge, UK, 2009.

187. Li, F.F.; Carlsson, D.; Lohmann, C.; Suuronen, E.; Vascotto, S.; Kobuch, K.; Sheardown, H.; Munger, R.; Nakamura, M.; Griffith, M. Cellular and nerve regeneration within a biosynthetic extracellular matrix for corneal transplantation. Proc. Natl. Acad. Sci. USA 2003, 100, 15346-15351.

188. McLaughlin, C.R.; Acosta, M.C.; Luna, C.; Liu, W.G.; Belmonte, C.; Griffith, M.; Gallar, J. Regeneration of functional nerves within full thickness collagen-phosphorylcholine corneal substitute implants in guinea pigs. Biomaterials 2010, 31, 2770-2778.

189. Nishida, T. Cornea: Fundamentals of Cornea and External Disease. In Cornea; Mosby-Year Book:

St. Louis, MO, USA, 1997. 
190. Olsen, D.; Yang, C.; Bodo, M.; Chang, R.; Leigh, S.; Baez, J.; Carmichael, D.; Perala, M.; Hamalainen, E.R.; Jarvinen, M.; et al. Recombinant collagen and gelatin for drug delivery. Adv. Drug Deliv. Rev. 2003, 55, 1547-1567.

191. Yang, C.; Hillas, P.J.; Baez, J.A.; Nokelainen, M.; Balan, J.; Tang, J.; Spiro, R.; Polarek, J.W. The application of recombinant human collagen in tissue engineering. BioDrugs 2004, 18, 103-119.

192. Merrett, K.; Fagerholm, P.; McLaughlin, C.R.; Dravida, S.; Lagali, N.; Shinozaki, N.; Watsky, M.A.; Munger, R.; Kato, Y.; Li, F.; et al. Tissue-engineered recombinant human collagen-based corneal substitutes for implantation: Performance of type I versus type III collagen. Investig. Ophthalmol. Vis. Sci. 2008, 49, 3887-3894.

193. Fagerholm, P.; Lagali, N.S.; Merrett, K.; Jackson, W.B.; Munger, R.; Liu, Y.; Polarek, J.W.; Soderqvist, M.; Griffith, M. A biosynthetic alternative to human donor tissue for inducing corneal regeneration: 24-month follow-up of a phase 1 clinical study. Sci. Transl. Med. 2010, 2, 46-61.

194. van Essen, T.H.; Lin, C.C.; Hussain, A.K.; Maas, S.; Lai, H.J.; Linnartz, H.; van den Berg, T.J.T.P.; Salvatori, D.C.F.; Luyten, G.P.M.; Jager, M.J. A fish scale-derived collagen matrix as artificial cornea in rats: Properties and potential. Investig. Ophthalmol. Vis. Sci. 2013, 54, 3224-3233.

195. Chen, M.H.; Li, Y.H.; Chang, Y.; Hu, S.Y.; Gong, H.Y.; Lin, G.H.; Chen, T.T.; Wu, J.L. Co-induction of hepatic IGF-I and progranulin mrna by growth hormone in tilapia, oreochromis mossambiccus. Gen. Comp. Endocrinol. 2007, 150, 212-218.

196. Okuda, M.; Ogawa, N.; Takeguchi, M.; Hashimoto, A.; Tagaya, M.; Chen, S.; Hanagata, N.; Ikoma, T. Minerals and aligned collagen fibrils in tilapia fish scales: Structural analysis using dark-field and energy-filtered transmission electron microscopy and electron tomography. Microsc. Microanal. 2011, 17, 788-798.

197. Lin, C.C.; Ritch, R.; Lin, S.M.; Ni, M.H.; Chang, Y.C.; Lu, Y.L.; Lai, H.J.; Lin, F.H. A new fish scale-derived scaffold for corneal regeneration. Eur. Cells Mater. 2010, 19, 50-57.

198. Sugiura, H.; Yunoki, S.; Kondo, E.; Ikoma, T.; Tanaka, J.; Yasuda, K. In vivo biological responses and bioresorption of tilapia scale collagen as a potential biomaterial. J. Biomat. Sci.-Polym. E 2009, 20, 1353-1368.

199. Matsusaki, M.; Amekawa, R.; Matsumoto, M.; Tanaka, Y.; Kubota, A.; Nishida, K.; Akashi, M. Physical and specific crosslinking of collagen fibers by supramolecular nanogelators. Adv. Mater. 2011, 23, 2957-2961.

200. Orwin, E.J.; Hubel, A. In vitro culture characteristics of corneal epithelial, endothelial, and keratocyte cells in a native collagen matrix. Tissue Eng. 2000, 6, 307-319.

201. Parnigotto, P.P.; Bassani, V.; Montesi, F.; Conconi, M.T. Bovine corneal stroma and epithelium reconstructed in vitro: Characterisation and response to surfactants. Eye 1998, 12, 304-310.

202. Germain, L.; Auger, F.A.; Grandbois, E.; Guignard, R.; Giasson, M.; Boisjoly, H.; Guerin, S.L. Reconstructed human cornea produced in vitro by tissue engineering. Pathobiol. J. Immunopathol. Mol. Cell. Biol. 1999, 67, 140-147.

203. Germain, L.; Carrier, P.; Auger, F.A.; Salesse, C.; Guerin, S.L. Can we produce a human corneal equivalent by tissue engineering? Prog. Retin. Eye Res. 2000, 19, 497-527.

204. Minami, Y.; Sugihara, H.; Oono, S. Reconstruction of cornea in three-dimensional collagen gel matrix culture. Investig. Ophthalmol. Vis. Sci. 1993, 34, 2316-2324. 
205. Tegtmeyer, S.; Reichl, S.; Muller-Goymann, C.C. Cultivation and characterization of a bovine in vitro model of the cornea. Die Pharmazie 2004, 59, 464-471.

206. Tegtmeyer, S.; Papantoniou, I.; Muller-Goymann, C.C. Reconstruction of an in vitro cornea and its use for drug permeation studies from different formulations containing pilocarpine hydrochloride. Eur. J. Pharm. Biopharm. 2001, 51, 119-125.

207. Zieske, J.D.; Mason, V.S.; Wasson, M.E.; Meunier, S.F.; Nolte, C.J.; Fukai, N.; Olsen, B.R.; Parenteau, N.L. Basement membrane assembly and differentiation of cultured corneal cells: Importance of culture environment and endothelial cell interaction. Exp. Cell Res. 1994, 214, 621-633.

208. Schneider, A.I.; Maier-Reif, K.; Graeve, T. The use of an in vitro cornea for predicting ocular toxicity. In vitro Toxicol. 1997, 10, 309-318.

209. Schneider, A.I.; Maier-Reif, K.; Graeve, T. Constructing an in vitro cornea from cultures of the three specific corneal cell types. In vitro Cell. Dev. Biol. Anim. 1999, 35, 515-526.

210. Reichl, S.; Muller-Goymann, C.C. Development of an organotypic corneal construction as an in vitro model for permeability studies. Ophthalmologe 2001, 98, 853-858.

211. Reichl, S.; Muller-Goymann, C.C. The use of a porcine organotypic cornea construct for permeation studies from formulations containing befunolol hydrochloride. Int. J. Pharm. 2003, 250, 191-201.

212. Zieske, J.D.; Chung, E.H.; Guo, X.Q.; Hutcheon, A.E.K. Human corneal organotypic cultures. J. Toxicol.-Cutan. Ocul. 2004, 23, 19-28.

213. Reichl, S.; Bednarz, J.; Müller-Goymann, C.C. Human corneal equivalent as cell culture model for in vitro drug permeation studies. Br. J. Ophthalmol. 2004, 88, 560-565.

214. Zorn-Kruppa, M.; Tykhonova, S.; Belge, G.; Bednarz, J.; Diehl, H.A.; Engelke, M. A human corneal equivalent constructed from sv40-immortalised corneal cell lines. Altern. Lab. Anim. 2005, 33, 37-45.

215. Reichl, S.; Dohring, S.; Bednarz, J.; Muller-Goymann, C.C. Human cornea construct HCC-An alternative for in vitro permeation studies? A comparison with human donor corneas. Eur. J. Pharm. Biopharm. 2005, 60, 305-308.

216. Andrew, J.P.; Allison, R.C. Polymer chemistry: Properties and Applications; Hanser Gardner Publications: Cincinatti, OH, USA, 2006.

217. Stupp, S.I.; Braun, P.V. Molecular Manipulation of Microstructures: Biomaterials, ceramics and semiconductors. Science 1997, 277, 1242-1248.

218. Pilla, S. Handbook of Bioplastics and Biocomposites Engineering Applications; Wiley: Hoboken NJ, USA, 2011.

219. Jenkins, A.D.; Kratochvìl, P.; Stepto, R.F.T.; Suter, U.W. Glossary of basic terms in polymer science. In Pure and Applied Chemistry; International Union of Pure and Applied Chemistry: Oxford, UK, 1996; Volume 68, pp. 2287-2301.

220. Meyers, M.A.; Chen, P.Y.; Yu-Min Lin, A.; Seki, Y. Biological materials: Structure \& mechanical properties. Progr. Mater. Sci. 2008, 53, 1-206.

221. Dohlman, C.; Harissi-Dagher, M. The boston keratoprosthesis: A new threadless design. Dig. J. Opthalmol. 2007, 13. Available online: http://www.djo.harvard.edu/print.php?url=/physicians/oa/ 1055\&print=1 (accessed on 5 September 2014). 
222. Ament, J.D.; Stryjewski, T.P.; Ciolino, J.B.; Todani, A.; Chodosh, J.; Dolhman, C.H. Cost-effectiveness of the Boston Keratoprosthesis. Am. J. Ophthalmol. 2010, 149, 221-228.

223. Klufas, M.A.; Colby, K.A. The Boston Keratoprosthesis. Int. Ophthalmol. Clin. 2010, 50, $161-175$.

224. Harissi-Dagher, M.; Dohlman, C.H. The boston keratoprosthesis in severe ocular trauma. Can. J. Ophthalmol. 2008, 43, 165-169.

225. Dohlman, C.H.; Harissi-Dagher, M.; Khan, F.B.; Sippel, K.; Aquavella, V.J.; Graney, M.J. Introduction to the use of the boston keratoprosthesis. Expert Rev. Ophthalmol. 2006, 1, 41-48.

226. Chew, H.F.; Ayres, B.D.; Hammersmith, K.M.; Rapuano, C.J.; Laibson, P.R.; Myers, J.S.; Jin, Y.P.; Cohen, E.J. Boston keratoprosthesis outcomes and complications. Cornea 2009, 28, 989-996.

227. Khan, B.F.; Harissi-Dagher, M.; Khan, D.M.; Dohlman, C.H. Advances in boston keratoprosthesis: Enhancing retention and prevention of infection and inflammation. Int. Ophthalmol. Clin. 2007, 47, 61-71.

228. Eguchi, H.; Hicks, C.R.; Crawford, G.J.; Tan, D.T.; Sutton, G.R. Cataract surgery with the alphacor artificial cornea. J. Cataract Refract. Surg. 2004, 30, 1486-1491.

229. Hicks, C.R.; Crawford, G.J.; Tan, D.T.; Snibson, G.R.; Sutton, G.L.; Gondhowiardjo, T.D.; Lam, D.S.; Downie, N. Outcomes of implantation of an artificial cornea, alphacor: Effects of prior ocular herpes simplex infection. Cornea 2002, 21, 685-690.

230. Hicks, C.R.; Hamilton, S. Retroprosthetic membranes in alphacor patients: Risk factors and prevention. Cornea 2005, 24, 692-698.

231. Bruining, M.J.; Pijpers, A.P.; Kingshott, P.; Koole, L.H. Studies on new polymeric biomaterials with tunable hydrophilicity, and their possible utility in corneal repair surgery. Biomaterials $\mathbf{2 0 0 2}$, 23, 1213-1219.

232. Griffith, M.; Osborne, R.; Munger, R.; Xiong, X.J.; Doillon, C.J.; Laycock, N.L.C.; Hakim, M.; Song, Y.; Watsky, M.A. Functional human corneal equivalents constructed from cell lines. Science 1999, 286, 2169-2172.

233. Griffith, M.; Hakim, M.; Shimmura, S.; Watsky, M.A.; Li, F.; Carlsson, D.; Doillon, C.J.; Nakamura, M.; Suuronen, E.; Shinozaki, N.; et al. Artificial human corneas: Scaffolds for transplantation and host regeneration. Cornea 2002, 21, S54-S61.

234. Li, F.; Griffith, M.; Li, Z.; Tanodekaew, S.; Sheardown, H.; Hakim, M.; Carlsson, D.J. Recruitment of multiple cell lines by collagen-synthetic copolymer matrices in corneal regeneration. Biomaterials 2005, 26, 3093-3104.

(C) 2014 by the authors; licensee MDPI, Basel, Switzerland. This article is an open access article distributed under the terms and conditions of the Creative Commons Attribution license (http://creativecommons.org/licenses/by/3.0/). 